AEC

RESEARCH

and

DEVELOPMENT

\section{REPORT}

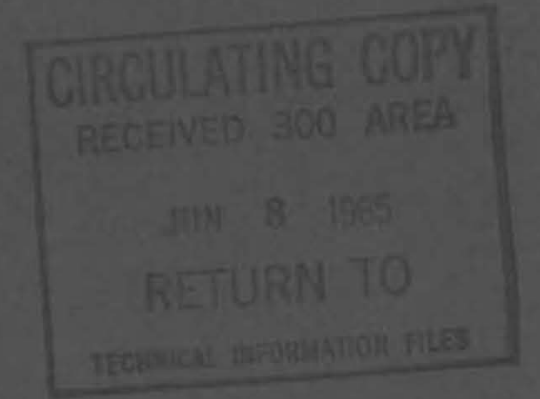

BNWL-32

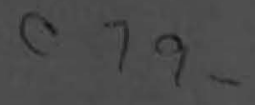

\title{
THE STEADY-STATE CREEP \\ OF HIGH-PURITY PLUTONIUM
}

JANUARY, 1965
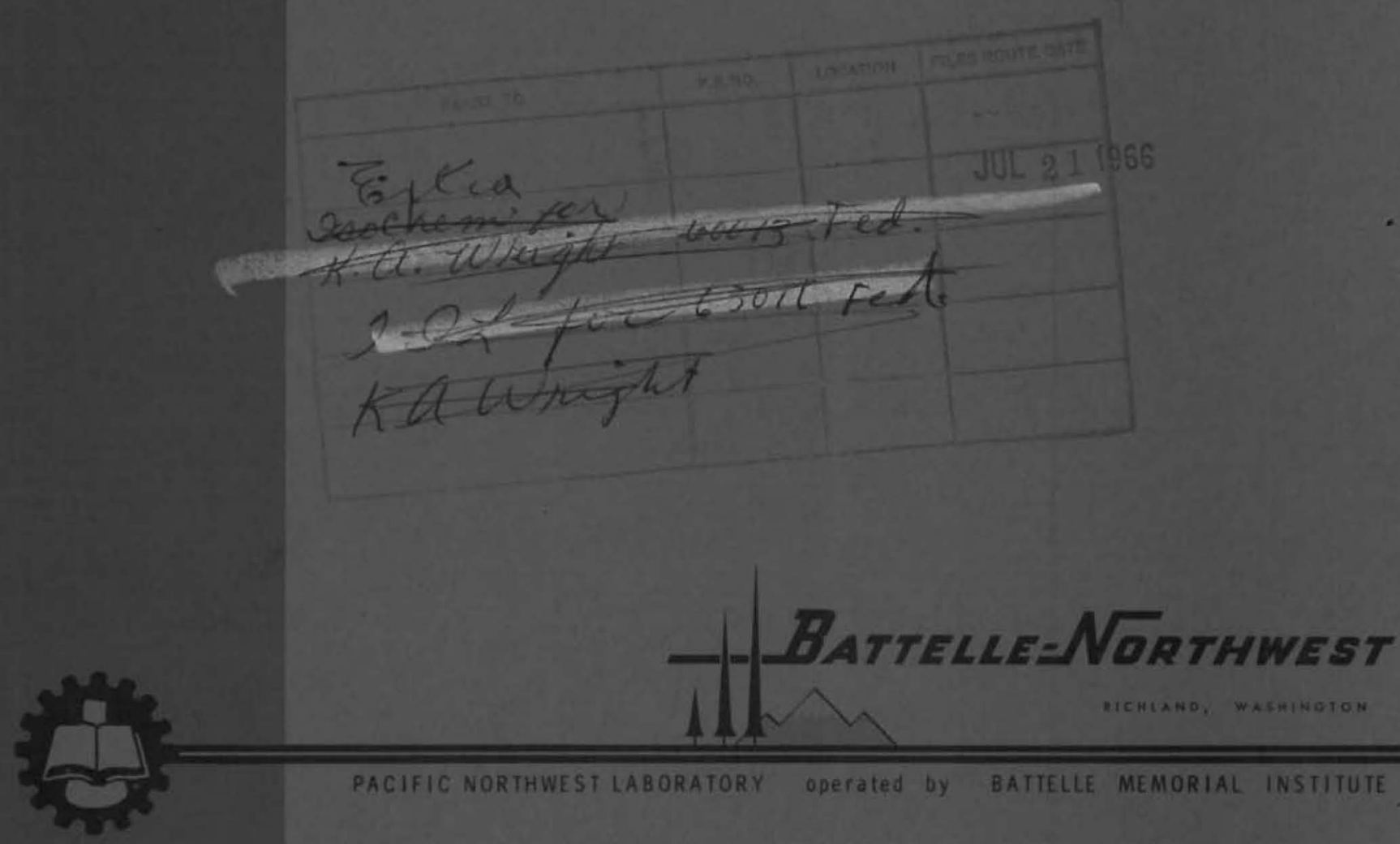


\section{LEGAL NOTICE}

This report was prepared as an account of Government sponsored work. Neither the United States, nor the Commission, nor any person acting on behalf of the Commission:

A. Makes any warranty or representation, expressed or implied, with respect to the accuracy, completeness, or usefulness of the information contained in this report, or that the use of any information, apparatus, method, or process disclosed in this report may not infringe privately owned rights; or

B. Assumes any liabilities with respect to the use of, or for damages resulting from the use of any information, apparatus, method, or process disclosed in this report.

As used in the above, "person acting on behalf of the Commission" includes any employee or contractor of the Commission, or employee of such contractor, to the extent that such employee or contractor of the Commission, or employee of such contractor prepares, disseminates, or provides access to, any information pursuant to his employment or contract with the Commission, or his employment with such contractor.

\section{PACIFIC NORTHWEST LABORATORY \\ RICHLAND, WASHINGTION \\ Operated By}

BATIELLE MEMORIAL INSTITUTE

For The

U. S. ATOMIC ENERGY COMMISSION Under Contract No. AT(45-1)-1830 
BNWL- 32

UC-25, Metals, Ceramics, and Materials

THE STEADY - STATE CREEP OF HIGH-PURITY PLUTONIUM

By

Met un a n

pistotian

65

R. D. Nelson, T. K. Bierlein, and F. E. Bowman

Metallurgy Research Section

Reactor and Materials Technology Department

January, 1965

PACIFIC NORTHWEST LABORATORY

RICHLAND, WASHINGTON 


\section{THE STEADY - STATE CREEP \\ OF HIGH-PURITY PLUTONIUM}

\section{INTRODUCTION}

This report presents results of steady-state, compressive creep experiments on the six allotropes of plutonium. These results are discussed and correlated with similar information about more common metals. Steady-state creep data were needed for the analysis of transformation creep data which provided information on the type of mechanism that might be responsible for these transformations.

\section{SUMMARY AND CONCLUSIONS}

Compressive creep experiments were performed on the six allotropes of plutonium at constant stress and isothermal conditions. The following conclusions were made:

- The creep rates of the aliotropes formed by heating a low temperature-stable allotrope decrease in the order of

$$
\varepsilon>\delta^{\prime}>\delta>\beta>\gamma>\alpha \text {. }
$$

- The creep rates of the allotropes formed by cooling a high temperature-stable aliotrope decrease in the order of

$$
\varepsilon>\delta^{\prime}>\delta>\gamma>\beta>\alpha \text {. }
$$

- For strains between $10^{-4}$ and $10^{-1} \mathrm{hr}-1$ the steady state creep rates of the beta and gamma phases vary as the fifth power of stress; the steady-state creep rate of the delta phase varies as the sixth power of stress.

- The average activation energies for steady-state creep based on an Arrhenius relationship are 26, 30, 35, 31, 28, and $25 \mathrm{kcal} / \mathrm{g}$ atom for the $\alpha, \beta, \gamma, \delta, \delta^{\prime}$, and $\epsilon$ phases, respectively.

- Activation energies for self-diffusion were calculated from an empirical expression that utilizes modulus compensated creep rates. These activation energies are $23,27,31,30,28$, and $25 \mathrm{kcal} / \mathrm{g}$-atom for the $\alpha, \beta, \gamma, \delta, \delta^{\prime}$, and $\varepsilon$ phases, respectively. 


\section{EXPERIMENTAL PARAMETERS}

The metal used in this investigation was high-purity as-reduced plutonium that had been vacuum melted and vacuum cast. The americium content was estimated to be $100 \mathrm{ppm}$. Typical impurity contents were: 50 ppm Fe, 60 ppm C, 50 ppm U, 20 ppm Ni, 10 ppm Al, 5 ppm Mg, and $10 \mathrm{ppm} \mathrm{Si}$; the concentration of all other impurities was considered to be less than $5 \mathrm{ppm}$. The high value for the density of the metal, greater than $19.60 \mathrm{~g} / \mathrm{cm}^{3}$, was considered to be a necessary confirmation of metal quality and purity. (1)

The compressive creep experiments were performed on solid cylindrical rod specimens. The metal was melted in a tantalum crucible by heating to $1000 \mathrm{C}$ in a vacuum of $10^{-4}$ torr and then cast into preheated graphite molds coated with a fused alumina and silica paint. The preheat temperature of the molds was $550 \mathrm{C}$. After the ingots had cooled to approximately $150 \mathrm{C}$, they were transferred to an oil bath at $110 \mathrm{C}$ and held at temperature for $2 \mathrm{hr}$ so the metal could transform completely to beta. Transformation of beta to alpha was accomplished by a procedure that minimizes microcracking introduced during the $\beta \rightarrow \alpha$ transformation. This procedure calls for quenching to a temperature of $-80 \mathrm{C}$ or lower followed by cycling between -80 and $+100 \mathrm{C}^{(2)}$ to transform any retained phases.

The rods were machined to a final diameter of either $0.200,0.250$, 0.375 , or $0.500 \mathrm{in}$. and cut to a length equal to one and one-half times the diameter. The 0.200 and 0.250 in. diameter specimens were used for alpha, beta, and gamma creep studies. Because the delta, delta-prime, and epsilon phases have creep rates which are high compared to those of the low temperature allotropes, larger, 0.375 and 0.500 in. diameter specimens were used for these phases. Barrelling and total strain for a given load is less in specimens with a large cross-section. Consequently errors in measurement are also reduced. The crystal structures of the allotropes of plutonium, temperature ranges of stability, and densities are given in Table $I$. 
TABLE I

CRYSTAL STRUCTURE, RANGES OF STABILITY, AND DENSITIES FOR PLUTONIUM ALLOTROPES

\begin{tabular}{|c|c|c|c|c|}
\hline Phase & $\begin{array}{l}\text { Crystal } \\
\text { Lattice } \\
\end{array}$ & $\begin{array}{l}\text { Number of } \\
\text { Atoms per } \\
\text { Structure } \\
\text { Cell }\end{array}$ & $\begin{array}{c}\text { Stability } \\
\text { Range, } \\
\text { C } \\
\end{array}$ & $\begin{array}{l}\text { Calculated } \\
\text { Density, } \\
\mathrm{g} / \mathrm{cm}^{3}\end{array}$ \\
\hline Alpha & $\begin{array}{l}\text { Simple } \\
\text { Monoclinic }\end{array}$ & 16 & Below 112 & $19.82(25 \mathrm{C})$ \\
\hline Beta & $\begin{array}{l}\text { Body-Centered } \\
\text { Monoclinic }\end{array}$ & 34 & $112-185$ & $17.8(150 \mathrm{C})$ \\
\hline Gamma & $\begin{array}{l}\text { Face-Centered } \\
\text { Orthorhombic }\end{array}$ & 8 & $185-310$ & 17. $14(235 \mathrm{C})$ \\
\hline Delta & $\begin{array}{l}\text { Face-Centered } \\
\text { Cubic }\end{array}$ & 4 & $310-451$ & $15.92(320 \mathrm{C})$ \\
\hline $\begin{array}{l}\text { Delta } \\
\text { Prime }\end{array}$ & $\begin{array}{l}\text { Body-Centered } \\
\text { Tetragonal }\end{array}$ & 2 & $451-480$ & $16.00(480 \mathrm{C})$ \\
\hline Epsilon & $\begin{array}{l}\text { Body-Centered } \\
\text { Cubic }\end{array}$ & 2 & $480-640$ & $16.51(510 \mathrm{C})$ \\
\hline
\end{tabular}

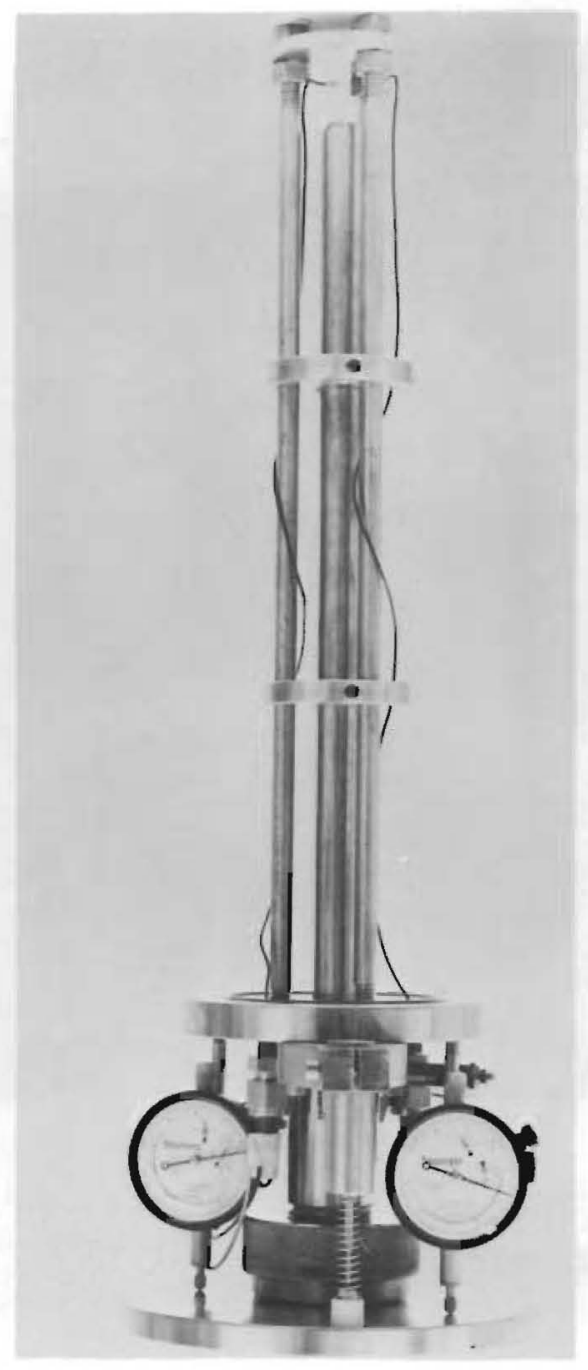

Creep testing was performed at a pressure of $10^{-3}$ torr in the apparatus shown in Figure 1. Tantalum sheet, $0.07 \mathrm{~mm}$ thick, was placed between the sample and the steel platens to prevent alloying of the plutonium and steel. Alloying occurs quite readily above $415 \mathrm{C}$ due to the formation of a low melting $\mathrm{Pu}-\mathrm{Pu}_{6} \mathrm{Fe}$ eutectic.

\section{FIGURE 1}

Apparatus in Which the Creep Neg. 0642372 
The experiments were performed in the glovebox shown in Figure 2. The flange of the furnace vacuum tube located below the glovebox, was welded directly to the floor of the glovebox. Power to the tube furnace heater equipped with a control thermocouple was supplied by a controllervariac combination. A thermocouple attached to the specimen showed that the temperature during an experiment was maintained within $\pm 1 \mathrm{C}^{0}$. Relative displacement of thə two platens was used as a measure of the creep strain of the specimen. Two externally positioned differential transformers sensitive to $0.0001 \mathrm{in.} \mathrm{changes} \mathrm{and} \mathrm{two} \mathrm{dial} \mathrm{indicators} \mathrm{graduated} \mathrm{in} \mathrm{units} \mathrm{of}$ 0.0001 in. were used. The engineering strain, (e), was determined as a function of time and then converted to true creep strain, $\epsilon$, by the relation$\operatorname{ship} \epsilon=\ln (1+e)$.

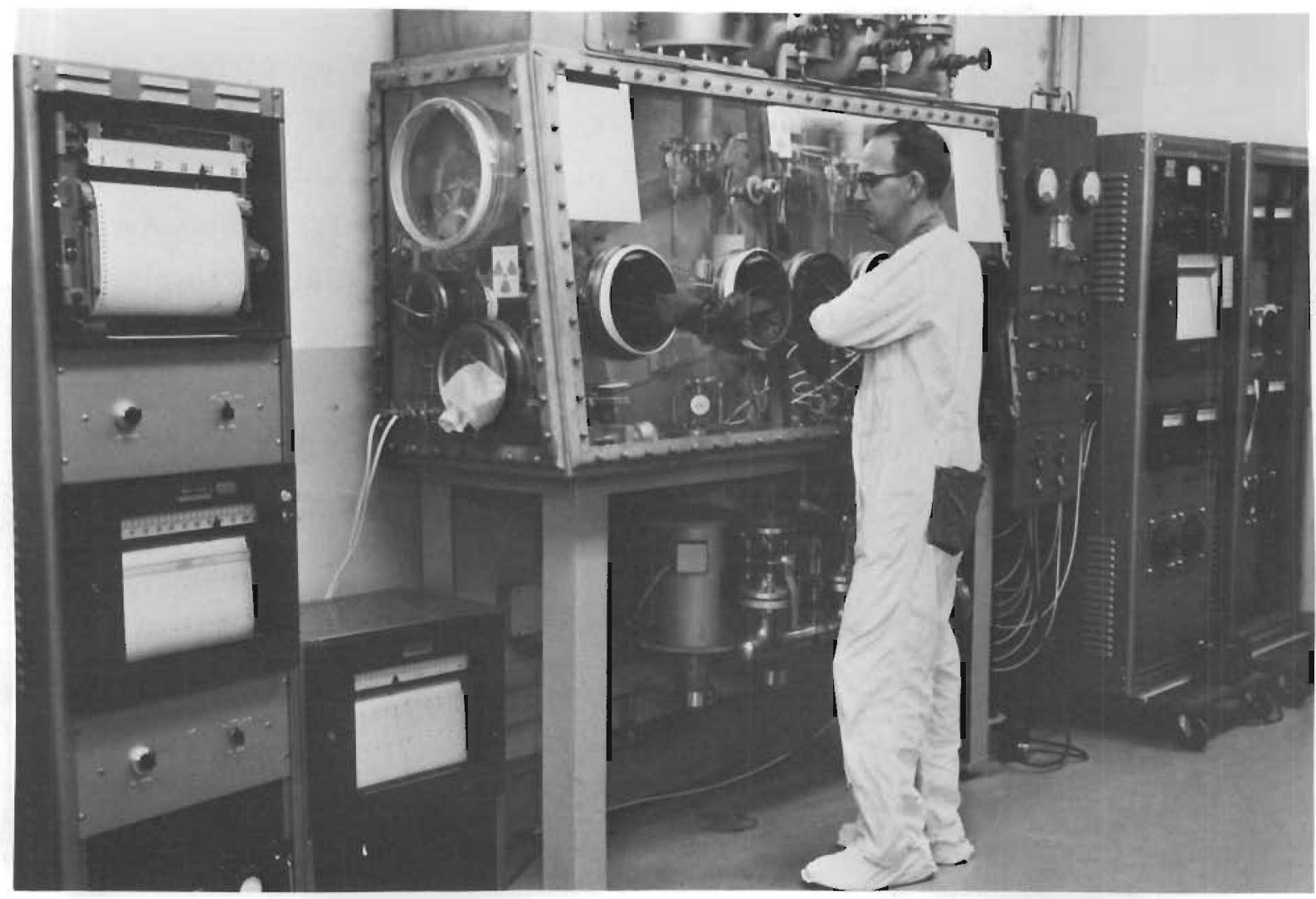

FIGURE 2

Glovebox and Instrumentation for Performing the Compression Creep Experiments

Neg. $34587-1$ 
The experiments were performed at constant stress under isothermal as well as under variable temperature conditions. The stress was maintained constant by increasing the load on the platen in direct proportion to the increase in the cross-sectional area of the specimens. The actual stress deviated from the prescribed stress by an amount less than $0.5 \%$. The determination of the cross-sectional area was based on the assumptions that the volume of the specimen remained constant, and that barrelling of the specimen did not occur during the test. Experimentally, the latter assumption was true for strains up to 0.20. Thus, the experiments were generally terminated before this strain was reached.

Before each test, the specimens were heated to a temperature high in the range of stability of the phase that was to be tested and held at this temperature for at least $2 \mathrm{hr}$. Specimens were then brought to the desired test temperature.

The data presented in this report apply only to specimens that were obtained by transformation from the phase stable at a low temperature to the phase stable at the higher temperature. For example, beta phase specimens were obtained by heating the specimens from the alpha phase region to $180 \mathrm{C}$, holding for $2 \mathrm{hr}$, and then cooling to the desired test temperature in the range of beta stability. Transforming specimens from a low temperature phase to the phase stable at the higher temperature was adopted as a standard procedure because the creep rate of beta formed from gamma was observed to be different than the creep rate of beta formed from alpha.

EXPERIMENTAL RESULTS

Representative compression creep curves obtained at different stresses and temperatures for the different allotropes of plutonium are shown in Figures 3 and 4 . The creep curves are typical in that they consist initially of primary creep followed by secondary or steady-state creep. 


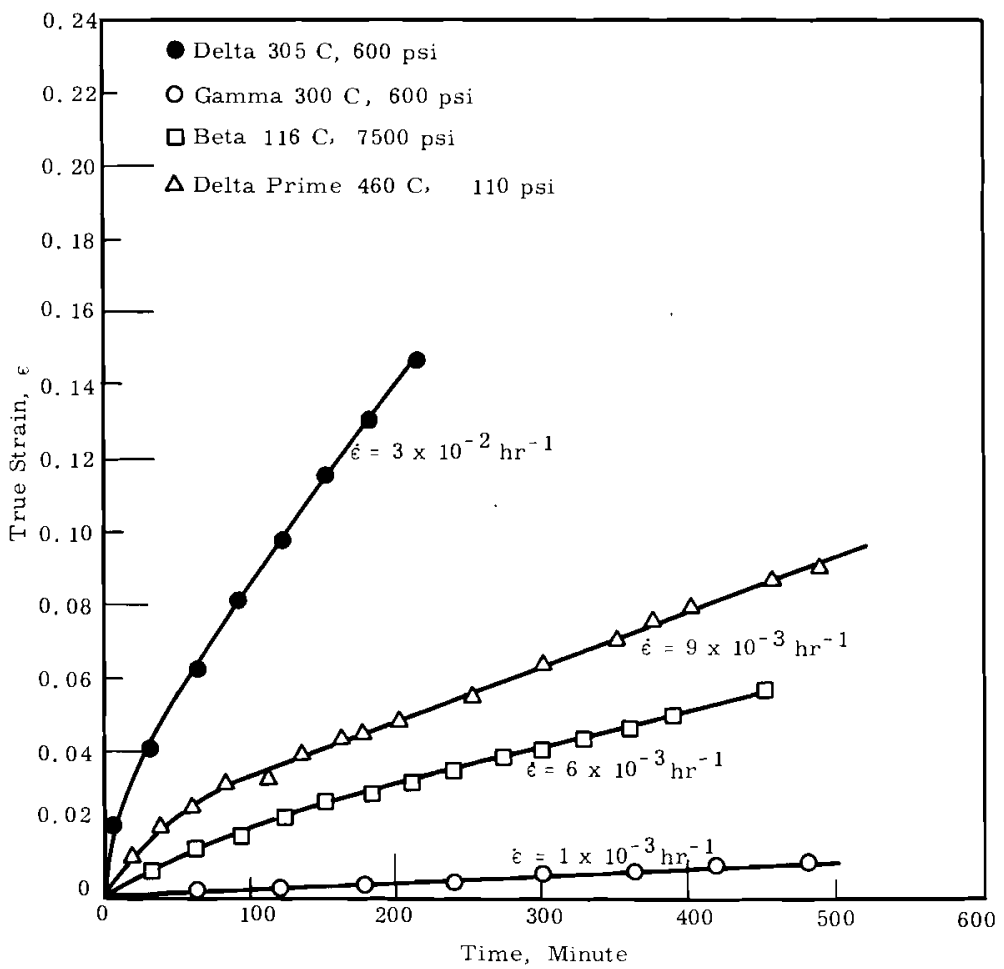

FIGURE 3

\section{Compression Creep Curves of Plutonium}

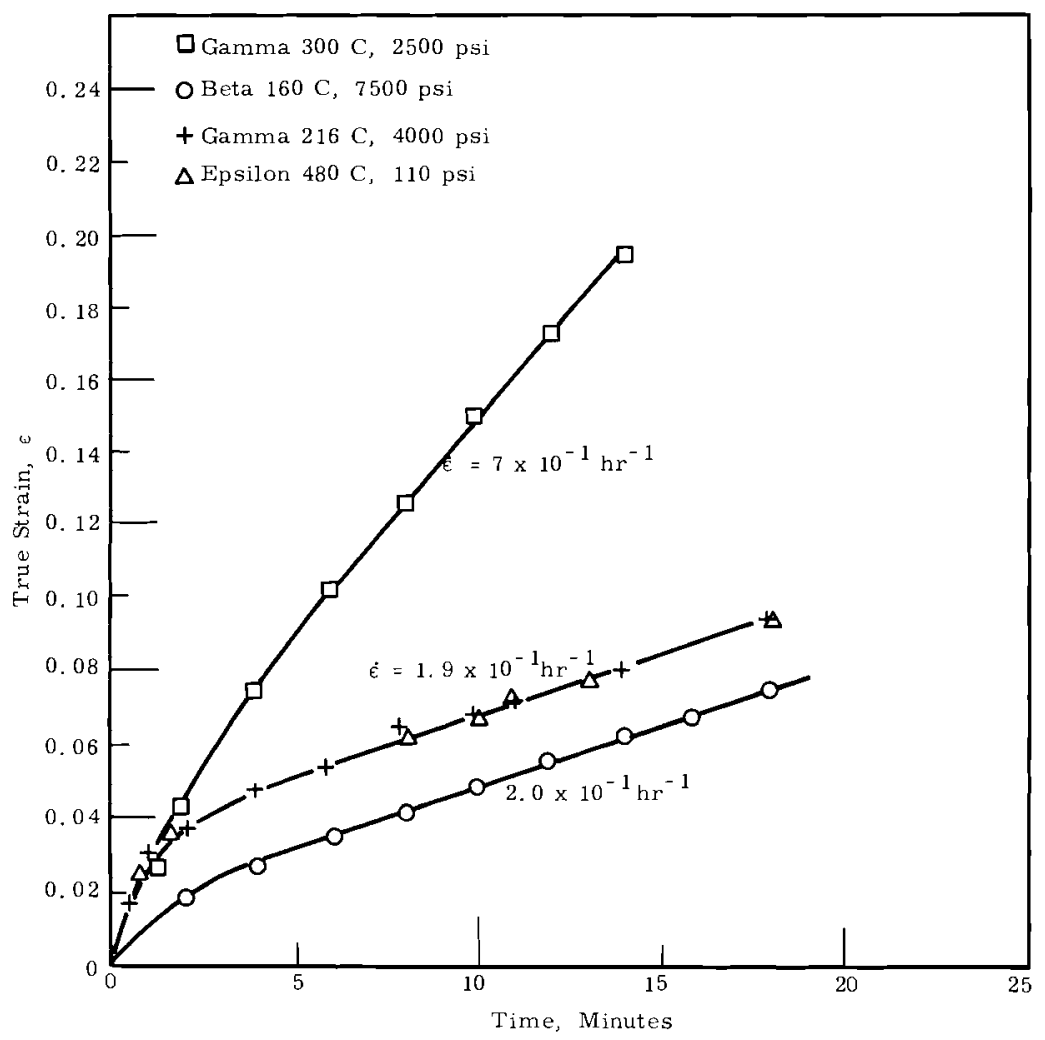

FIGURE 4

Compressive Creep Curves of Plutonium 
Sherby has derived an empirical expression relating strain rate to temperature and stress. (4) A more recent version of this equation has the form $(5,6)$

where

$$
\varepsilon=K \gamma^{3.5} \mathrm{D}\left(\frac{\sigma}{\mathrm{E}}\right)^{\mathrm{n}}
$$

$$
\begin{aligned}
& \mathrm{K}=\text { constant for all metals } \\
& Y=\text { stacking fault energy } \\
& \sigma=\text { applied stress } \\
& \mathrm{n}=\text { constant equal to about } 5 \\
& \mathrm{E}=\text { modulus of elasticity } \\
& \mathrm{D}=\mathrm{D}_{\mathrm{O}} \mathrm{e}^{-\mathrm{Q}_{\mathrm{sd}} / \mathrm{RT}} .
\end{aligned}
$$

In the expression for $\mathrm{D}$,

$$
\begin{aligned}
D_{\mathrm{O}} & =\text { universal constant } \\
\mathrm{Q}_{\mathrm{sd}} & =\text { activation energy for self diffusion } \\
\mathrm{T} & =\text { test temperature in degrees Kelvin } \\
\mathrm{R} & =\text { universal gas constant. }
\end{aligned}
$$

The original equation ${ }^{(4)}$ contained a grain size term; the more recent equation is grain size independent. Because the grain size of the allotropes, excluding alpha, can be neither determined nor maintained constant, the new form of the equation has obvious advantages in analyzing creep data of several allotropes of the same metal. The stacking fault energies of the six allotropes of plutonium are not known, but they were assumed to be constant during the creep tests. The values for the modulii of elasticity of the different allotropes over a range of temperatures are given in Table II.

TABLE II

\begin{tabular}{lcc} 
& \multicolumn{2}{c}{ VALUES FOR THE MODULUS OF ELASTICITY } \\
\cline { 2 - 3 } Phase & $\begin{array}{c}\text { Temperature } \\
\text { Alpha }\end{array}$ & $\begin{array}{c}\text { Modulus of Elasticity, } \\
\text { psi }\end{array}$ \\
\cline { 2 - 3 } Beta & 115 & $12.3 \times 10^{6}$ \\
Beta & 115 & 6.2 \\
Gamma & 185 & 5.5 \\
Gamma & 185 & 5.5 \\
Delta & 305 & 4.6 \\
Delta & 305 & 2.5 \\
Delta Prime & 450 & 2.4 \\
Epsilon & 450 & (a) \\
Epsilon & 475 & (a) \\
Ep & 475 & (a)
\end{tabular}

(a) No modulus of elasticity values available. 
Sufficient data were obtained for some of the allotropes to conclude that there was a range of strain rate values where $\mathrm{n}$ is a constant and is approximately equal to 5 . For low values of $\dot{\varepsilon}, \mathrm{n}$ is less than 5 , and for high strain rates $\mathrm{n}$ is greater than 5 . Most of the experimental work was performed at stresses where $\dot{\epsilon} \propto\left(\frac{\sigma}{\mathrm{E}}\right)^{5}$. The applied stress was compensated for the modulus of elasticity according to Equation (1) so that the ratio $\frac{\sigma}{\mathrm{E}}$ would remain constant at different temperatures. Representative data showing the dependency of the creep rates of the beta, gamma, and delta phases on the modulus compensated stress, i. e., $\frac{\sigma}{\mathrm{E}}$, are shown in Figures 5 through 7. It is apparent from Figure 5 that $n$ has a value of 6 for delta; $\mathrm{n}$ has a value of 5 for most metals.

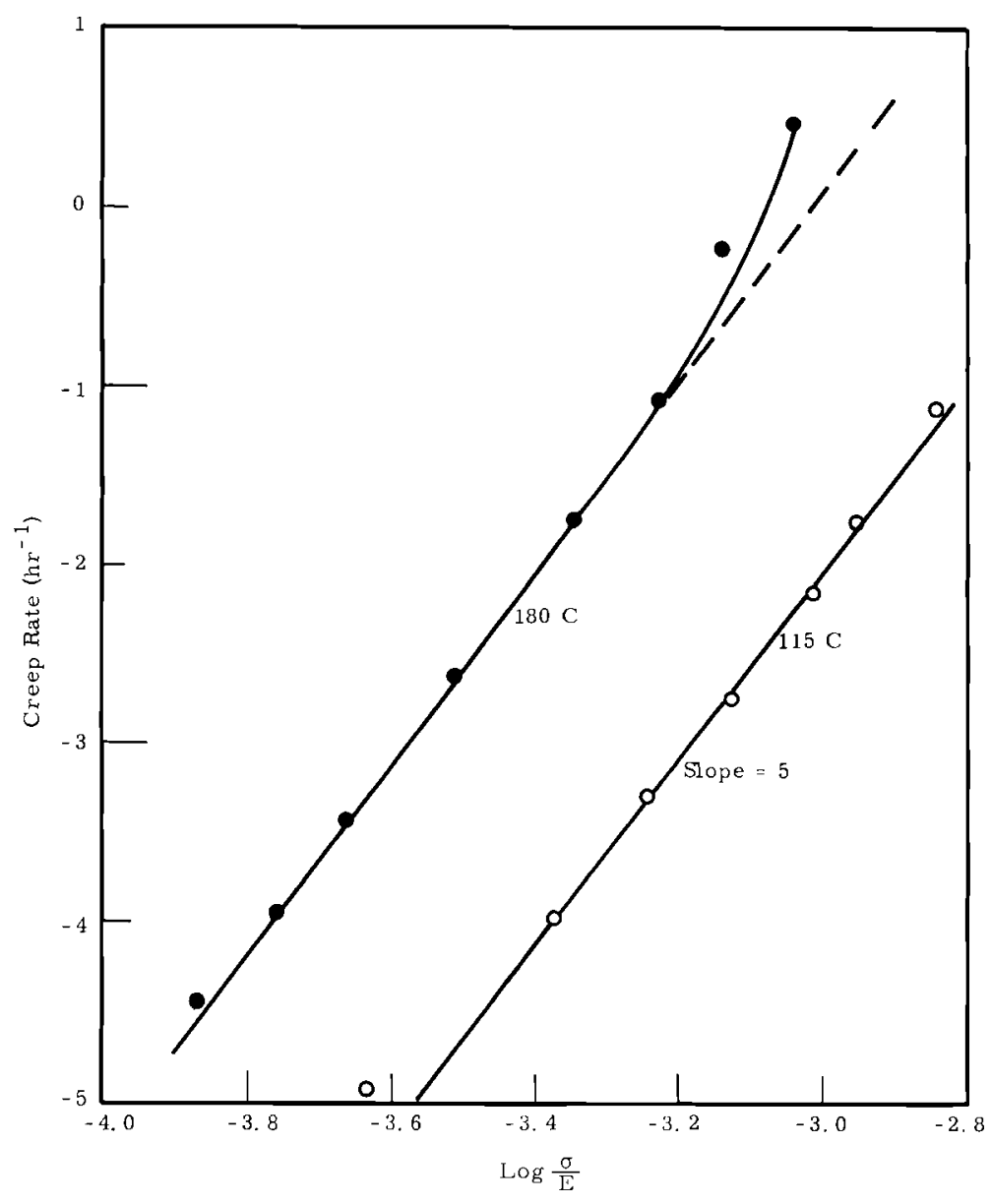

FIGURE 5

Dependency of the Creep Rate of Beta Plutonium on $\frac{\sigma}{\mathrm{E}}$ 
$-10-$
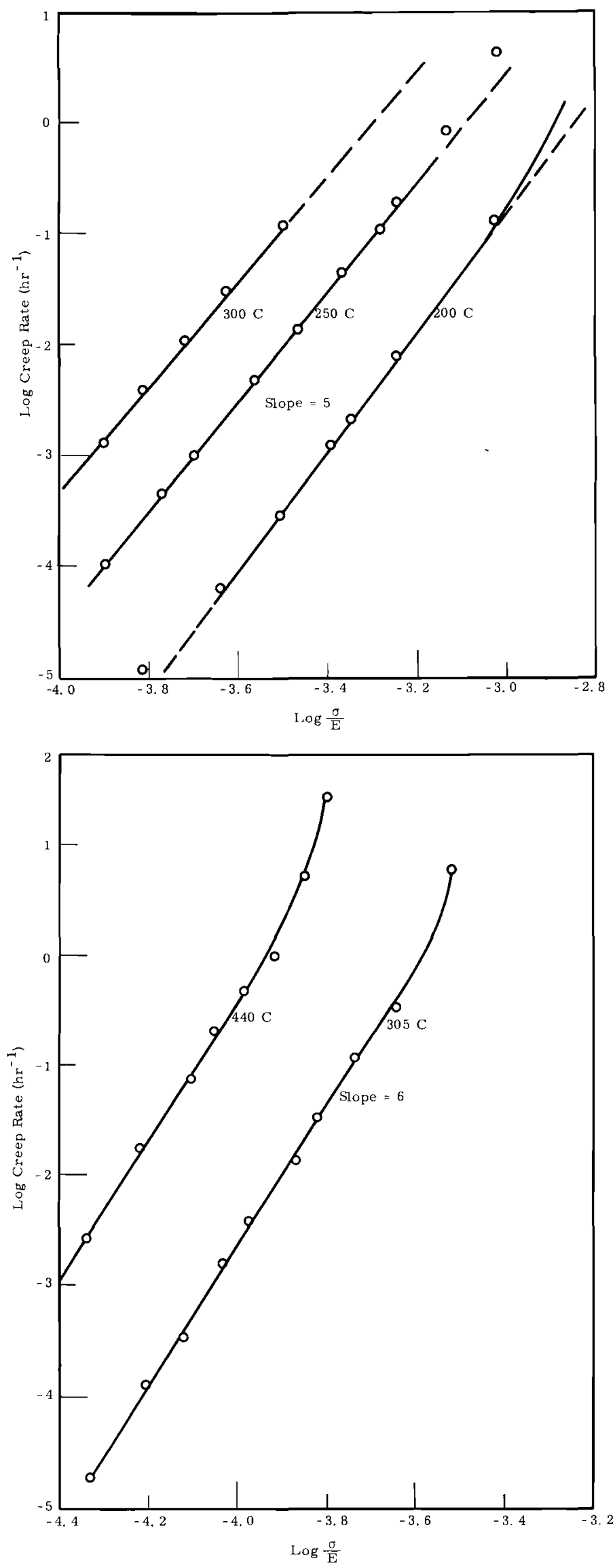

BNWL- 32

\section{FIGURE 6}

Dependency of the

Creep Rate of Gamma

Plutonium on $\frac{\sigma}{\mathrm{E}}$

\section{FIGURE 7}

Dependency of the Creep Rate of Delta Plutonium $\frac{\sigma}{\mathrm{E}}$ 
Because the creep rate of the alpha phase was low at stresses below $15,000 \mathrm{psi}$, and because the stable temperature ranges of the delta-prime and epsilon phases are relatively high, only a limited amount of data was obtained on the creep of the alpha, delta-prime, and epsilon phases. Only enough data on these three phases were obtained to compare all six of the allotropes.

Figure 8 permits a comparison of the logarithm of the steady-state creep rate versus reciprocal temperature for all plutonium allotropes. There was a very marked difference between the creep rates at the same stress of two, single phase allotropes, one stable and the other unstable, that can each exist at temperatures where transformation is extremely sluggish. If the creep rate and temperature are related by the Arrhenius equation, $\dot{\varepsilon}=A e^{-Q_{C} / R T}$, then the creep activation energy can be determined from the slope of the plots in Figure 8, i. e.

$$
Q_{C}=-\frac{2.3 R d \log \dot{\varepsilon}}{d(1 / T)}
$$

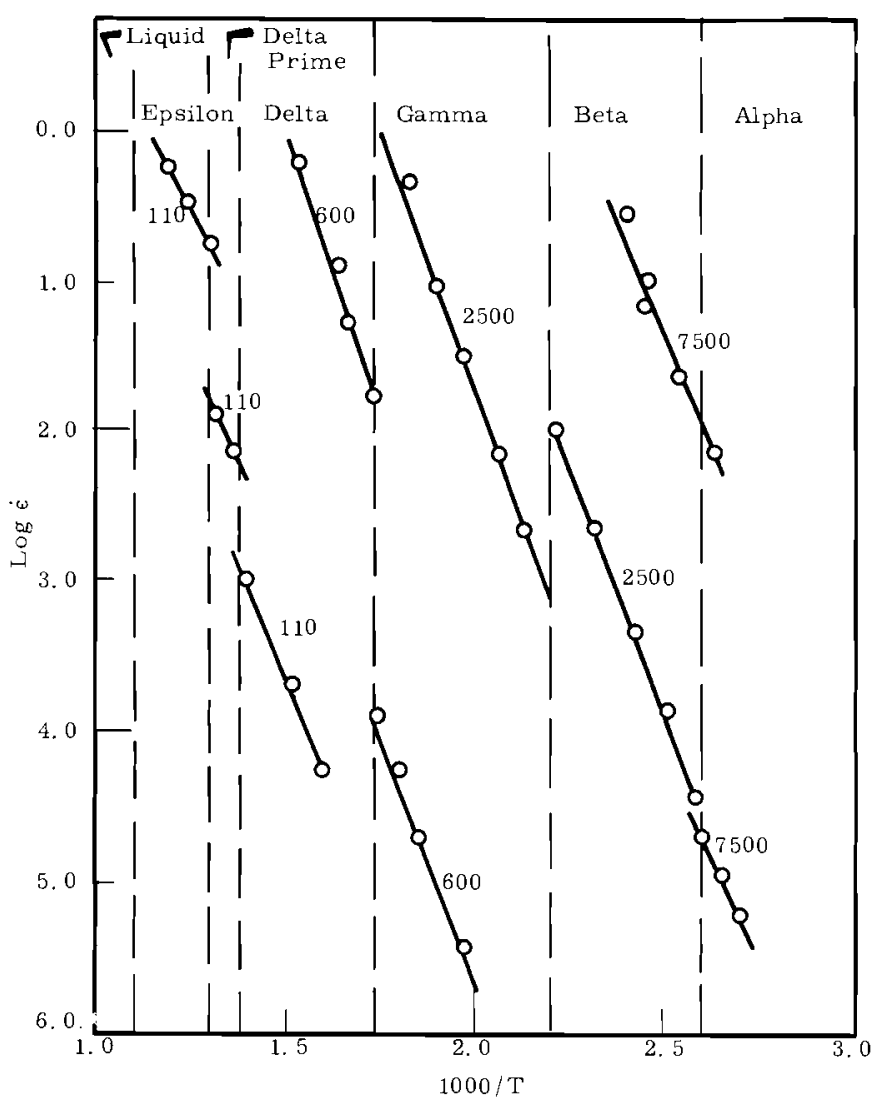

FIGURE 8

Temperature Dependency of the Creep of Plutonium (The creep stresses are in psi.) 
The average values for $Q_{c}$ are $26,30,35,31,28$, and $25 \mathrm{kcal} / \mathrm{g}$-atom, respectively, for the $\alpha, \beta, \gamma, \delta, \delta^{\prime}$, and $\epsilon$ phases. The activation energy, $Q_{C}$, is related to the self-diffusion activation energy by the relationship:

$$
Q_{C}=Q_{S d}-\frac{n R T^{2}}{E} \frac{d E}{d T}
$$

At a given temperature the creep rate of the phase normally stable at higher temperatures is greater than the creep rate of the phase normally stable at the lower temperatures with but one exception--the creep rate of gamma is less than the creep rate of the beta phase near the $\beta \rightleftarrows \gamma$ equilibrium transformation temperature. It is to be noted that this exception applies only to beta that is formed from alpha. The creep rate of beta material formed from alpha is 200 to 500 times greater than the creep rate of beta formed from gamma tested at the same temperature and stress conditions. Consequently, the creep rate of beta that is formed from gamma is less than the creep rate of the gamma phase under the same temperature and stress conditions. The effect of prior transformation on the mechanical properties of beta plutonium will be discussed in a subsequent report.

The activation energy for self-diffusion can be calculated from the strain rates at two temperatures according to the relationship:

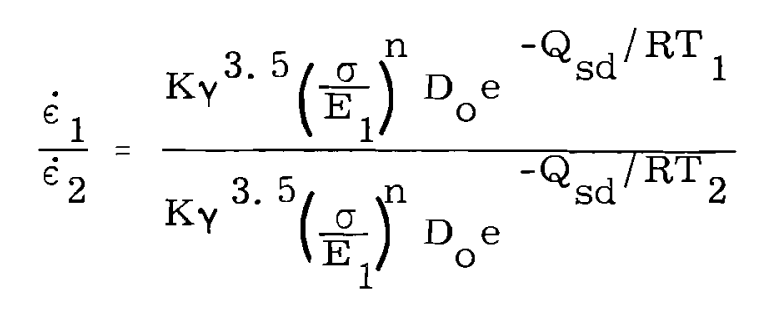

If the ratio $\frac{\sigma}{\mathrm{E}}$ is held constant by experimentally changing $\sigma$ to compensate for the temperature dependency of $E$, then the relationship becomes:

$$
\left.\frac{\dot{\varepsilon}_{1}}{\dot{\epsilon}_{2}}=\frac{\mathrm{e}^{-\mathrm{Q}_{\mathrm{Sd}} / \mathrm{RT}} 1}{\mathrm{e}^{-\mathrm{Q}_{\mathrm{Sd}} / \mathrm{RT}} 2} \text { (Constant } \frac{\sigma}{\mathrm{E}}\right)
$$


The activation energy, $Q_{\text {sd }}$, can also be calculated at constant stress using known values of $\mathrm{E}$ and $\mathrm{n}$ from the relationship:

$$
\frac{\dot{\epsilon}_{1} E_{1}^{n}}{\dot{\epsilon}_{2} E_{2}^{n}}=\frac{e^{-Q_{s d} / R T_{1}}}{e^{-Q_{s d} / R T_{2}}}
$$

In the present investigation the technique of holding the stress constant and compensating for the modulus was used rather than holding $\frac{\sigma}{\mathrm{E}}$ constant. Representative data of the temperature dependency of the modulus compensated strain rate are given in Figure 9. The modulii used for compensating the strains of the delta-prime and epsilon phases were extrapolated values. The difference between the modulus compensated strain rates of two phases at their mutual transformation temperature, apparent in Figure 9, is generally less than the difference between the noncompensated strain rates, Figure 8 . This is because the modulus of elasticity of the stable phase above the transformation temperature is generally less than that of the stable phase below the transformation temperature; an exception is the beta and gamma phases at the $\beta \rightleftarrows \gamma$ transformation temperature, where $E_{v}=E_{\beta}$. It is also apparent from Figure 9 that the strain rate of the higher temperature phase for a given stress is generally greater than the strain rate of the lower temperature phase; an exception to this generalization is that the strain rate of the gamma phase is less than the strain rate of the beta phase, if the beta phase is formed from alpha.

The activation energy for self-diffusion can be obtained from the slope of the curves shown in Figure 9. The average activation energies that have been calculated for the six allotropes are given in Table III. These activation energies are for stresses where $\mathrm{n} .=5$ in the proportionality $\dot{\epsilon} \propto\left(\frac{\sigma}{\mathrm{E}}\right)^{\mathrm{n}}$. Additional data, not included, tend to show that the activation energies are higher at stresses when $\mathrm{n}>5$, and they are lower when $\mathrm{n}<5$.

With the calculated self-diffusion activation energies substituted into Equation (1), creep data obtained for the six allotropes can be presented in the form shown in Figure 10 , where $\log \dot{e} \mathrm{e}^{\mathrm{Q} / \mathrm{RT}}$ is plotted as a function of $\log \left(\frac{\sigma}{\mathrm{E}}\right)$. The slopes of the curves correspond to the exponent $\mathrm{n}$. The 


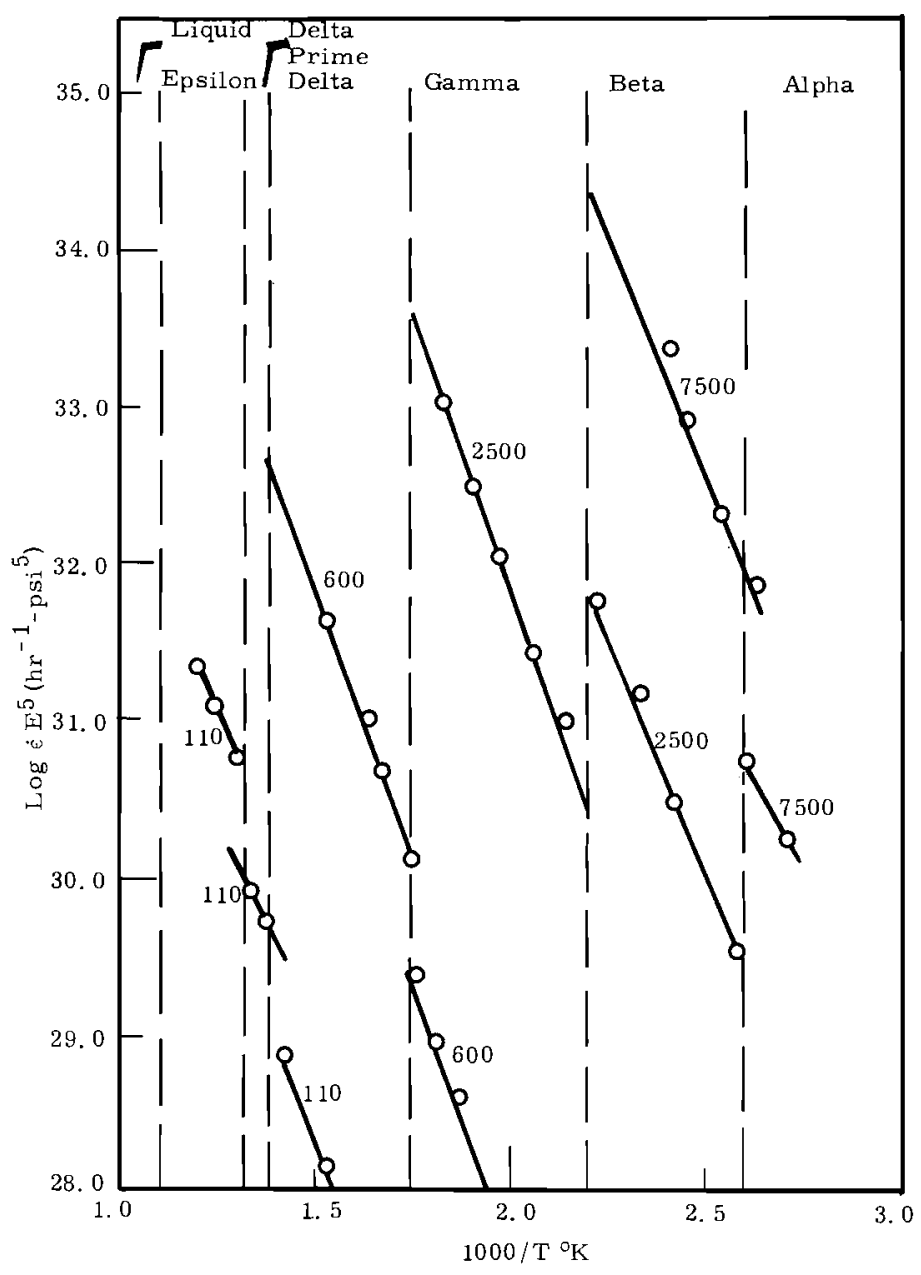

FIGURE 9

Modulus Compensated Creep Rate Versus Reciprocal Temperature for the Six Allotropes of Plutonium

TABLE III

CHANGES, TEMPERATURES, ENERGIES, AND STRUCTURE FACTORS FOR THE SIX ALLOTROPES OF PLUTONIUM

\begin{tabular}{|c|c|c|c|c|c|c|c|}
\hline \multirow[b]{2}{*}{ Phase } & \multicolumn{2}{|c|}{$\begin{array}{c}\text { Enthalpy and } \\
\text { Entropy Changes for } \\
\text { Normal Transformation } \\
\text { cal/g-atom }(11) \\
\end{array}$} & \multicolumn{2}{|c|}{$\begin{array}{l}\mathrm{T}_{\mathrm{m}} \\
\text { Effective } \\
\text { Melting } \\
\text { Temperature }\end{array}$} & \multicolumn{2}{|c|}{$\begin{array}{c}\text { Activation } \\
\text { Energy, } \\
\text { kcal/g-atom }\end{array}$} & \multirow{2}{*}{$\begin{array}{c}\text { Structure } \\
\text { Factor } \\
\left(\mathrm{K}_{\mathrm{O}}+\mathrm{V}\right) \\
\end{array}$} \\
\hline & $\Delta \mathrm{H}^{\mathrm{i} \rightleftharpoons(\mathrm{i}+1)}$ & $\Delta S^{i \neq(i+1)}$ & $\begin{array}{l}\underline{T e m} \\
\underline{\mathrm{K}}\end{array}$ & $\frac{\mathrm{re}}{\mathrm{C}}$ & $Q_{c}^{(a)}$ & $Q_{\mathrm{sd}}^{(\mathrm{b})}$ & \\
\hline$\alpha$ & 900 & 2. 28 & 557 & 284 & 26 & 23 & 21 \\
\hline$\beta$ & 160 & 0.33 & 748 & 475 & 30 & 27 & 18 \\
\hline$Y$ & 148 & 0.25 & 804 & 531 & 35 & 31 & 19.5 \\
\hline$\delta$ & 10 & 0.01 & 843 & 570 & 31 & 30 & 18 \\
\hline 8 & 444 & 0.59 & 842 & 569 & 28 & & $17^{(\mathrm{d})}$ \\
\hline$\varepsilon$ & 676 & 0.74 & 913 & 640 & 25 & & $14^{(\mathrm{d})}$ \\
\hline
\end{tabular}
(a) Derived from Figure 8
(b) Derived from Figure 9
(c) $\left(K_{o}+V\right)=\frac{Q_{s d}}{R T_{m}}$
(d) $Q_{C}$ was assumed equal to $Q_{S d}$ 




FIGURE 10

Creep Data Correlated According to the Proportionality $\dot{\varepsilon} e^{Q_{\text {sd }} / R T} \propto\left(\frac{\sigma}{\mathrm{E}}\right)^{n}$

difference in the values of $\dot{\varepsilon} \mathrm{e}^{\mathrm{Q}_{\mathrm{Sd}} / \mathrm{RT}}$ at constant $\left(\frac{\sigma}{\mathrm{E}}\right)$ for the allotropes other than alpha can be attributed to differences in stacking fault energies. These data imply that there is little difference in stacking fault energy of the beta, gamma, delta, delta-prime, and epsilon phases.

For the data of the alpha phase to correspond to this model, the stacking fault energy would have to be one-tenth the stacking fault energy of the higher temperature phase. More detailed experiments on creep of alpha plutonium may reveal that the activation energy, $Q_{\text {sd }}$, of alpha is greater than $23 \mathrm{kcal} / \mathrm{g}$-atom. It should be remembered that creep of the alpha phase may not be described by Equation (1). 
Using tracer techniques, Tate and Cramer ${ }^{(10)}$ obtained an activation energy of $23.8 \mathrm{kcal} / \mathrm{g}$-atom for self-diffusion of the delta phase of plutonium between 350 and $440 \mathrm{C}$. Their value is somewhat lower than the val ue of $30 \mathrm{kcal} / \mathrm{g}$-atom derived from the creep data. No diffusion data are available to make similar comparisons between activation energies for creep and self-diffusion for the other allotropes.

Sherby and Simnad ${ }^{(12)}$ derived an expression for the self-diffusion activation energy, $Q_{\text {sd, }}$ in terms of the effect of absolute melting temperature, $\mathrm{T}_{\mathrm{m}}$; the valence, $\mathrm{V}$; and a crystal structure parameter, $\mathrm{K}_{\mathrm{O}}$. Their relationship is:

$$
\mathrm{Q}_{\mathrm{sd}}=R \mathrm{~T}_{\mathrm{m}}\left(\mathrm{K}_{\mathrm{O}}+\mathrm{V}\right)
$$

The effective melting temperature is essentially the theoretical melting temperature of an allotrope. If the liquid, epsilon, delta-prime, delta, gamma, beta, and alpha phases are designated $0,1,2,3,4,5$, and 6 , respectively, then the effective melting temperature of each phase can be calculated according to the method derived by $\operatorname{Ardell}^{(13)}$, i. e.,

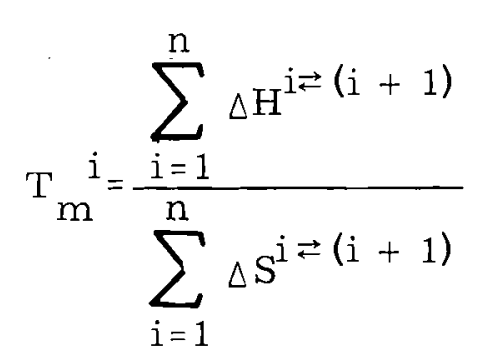

In this expression $\Delta H^{i \rightleftarrows(i+1)}$ and $\Delta S^{i \rightleftarrows(i+1)}$ are the enthalpy and entropy changes associated with the transformation of a particular phase to the next higher temperature phase. The effective melting temperatures of all six allotropes calculated in this manner are tabulated in Table III. The enthalpy and entropy changes associated with each transformatin used in these calculations are also listed in Table III. Ianniello ${ }^{(14)}$ calculated the effective melting temperature to be $622 \mathrm{~K}$, which is slightly higher than the value calculated by Ardell's method. The fact that every transformation temperature is greater than $0.5 \mathrm{~T}_{\mathrm{m}}$ is noteworthy. 
Plutonium offers a unique opportunity to determine the values of six crystal structure factors for a single metal. From the activation energies and the effective melting temperatures in Table III, values for $\left(\mathrm{K}_{\mathrm{O}}+\mathrm{V}\right)$ can readily be calculated from the expression:

$$
\mathrm{K}_{\mathrm{O}}+\mathrm{V}=\frac{\mathrm{Q}_{\mathrm{sd}}}{R \mathrm{~T}_{\mathrm{m}}} .
$$

The values calculated for $\left(\mathrm{K}_{\mathrm{O}}+\mathrm{V}\right)$ of all six allotropes are given in Table III.

Unfortunately, values for $\mathrm{V}$ in the above relationship have not been established. Sherby and Simnad ${ }^{(12)}$ assigned zero to $V$ for uranium. By analogy, zero for $V$ may also be applicable to plutonium. However, the significance of such a value for the valency term would be very doubtful. If $V$ does equal zero, then values for $K_{0}$ will be the same as the values given for $\left(K_{O}+V\right)$ in Table III.

Sherby and Simnad ${ }^{(12)}$ determined $K_{0}$ to be 14,17 , and 21 for the body-centered cubic, face-centered cubic, and diamond structures, respectively. If $\mathrm{V}=0$, the $\mathrm{K}_{\mathrm{O}}$ for the body-centered cubic and face-centered cubic allotropes of plutonium are 14 and 18 which are essentially in agreement with Sherby's and Simnad's values derived from other metals.

\section{ACKNOWLEDGMENTS}

Thanks are extended to A. G. Graybeal, R. S. Hagan, and A. S. Cole for their assistance in performing the experimental work. Special thanks are due C. R. Becker for installation of the experimental apparatus and instrumentation. 


\section{REFERENCES}

1. R. D. Nelson, Co R. Becker, T.K. Bierlein, and F. E。 Bowman。 Density Determinations of Plutonium, HW-80841 (General Electric Company, Richland, Washingtor,. February 1964.

2. R. D. Nelson, T。 K. Bierleir, and $F_{\circ}$ E。 Bowman。 Physical Damage in Plutonium, HW-80808 (General Electric Compary, Richlard, Washington), February 1964 .

3. J.J. Cadwell, et al. Quarteriy Progress Report Metallurgy Research Operation, July, August, September, 1964, HW-84281 Coeneral Electric Company, Richland, Washington! September 1964.

4. O. D. Sherby. "Factors Affecting the High Temperature Strength of Polycrystalline Solids," Acta Met. vol. 11, p. 591. 1963.

5. O. D. Sherby, Personal Communication. Stanford University. November 18, 1964.

6. C. R. Barrett. The Influence of Grain Boundaries and Stacking Fauts on High Temperature Plastic Deformation, $\mathrm{Ph}$. $\mathrm{D}$. Dissertation, Stanford University. October 1,1964 .

7. H. R. Gardner, Personal Communication. General Electric Company, Hanford Atomic Products Operation. July 1964.

8. C. R. Barrett, A. I. Ardell, and O, D. Sheroy。 "Influence of Modilus of the Temperature Dependence of the Activation Energy for Creep at High Temperature, "Trans, AIME, vol。230, p.200。1964.

9. J。J. Cadwell, et a1. Quarterly Progress Report, Metallurgy Research Operation, April, May, June, 1963 , HW-77954 General Electric Company, Richland, Washington!. July 1963.

10。 R. E. Tate and E, M. Cramer. "Self-Diffusion Studies of Deita Plutonium, "Trans. AIME, vol.230, p。639. 1964.

11. R. N. R. Mulford. Thermodynamic Functions for Pure Plotorium, LA-2813 (Los Alamos Scientific Laboratory) Janury 1963.

12. O. D. Sherby and M. T. Simnad "Prediction of Atomic Mobility in Metallic Systems, "Trans. Amer. Soc. Met, vol 54, p. 227. 1961.

13. A. J. Ardell. "On the Calculation of Meiting Temperatures of Low Temperature Phases of Polymorphic Metals." Acta Met., vol. 10, p. 135. 1962。

14. L. Ianniello. "The Recrystallization of Alpha Plutonium, "Trans Amer. Soc. Met... vol. 57, p. 768. 1964. 
INTERNAL DISTRIBUTION

Copy Number

F. W. Albaugh

H. W. Arrowsmith

V. C. Asmund

A. L. Bement

T. K. Bierlein

F. E. Bowman

J. L. Brimhall

H. L. Butts

J. J. Cadwell

A. S. Cole

R. L. Dillon

R. E. Falkoski

$H$, R. Gardner

S. M. Gill

R. S. Hagan

G. P. Hanneman

W. S. Hartnett

D. D. Hays

Y. B. Katayama

$R$. R. King, Jr.

$H$. E. Kissinger

J. J. Laidler

G. A. Last

R. D。 Leggett

B. Mastel

K. R. Merckx

J. E. Minor

27

$28-67$

68

69

R. D. Nelson

T. C. Nelson

F. A. Smidt

R. W. Stewart

71

72

73

74

75

H. A. Taylor

J. M. Taylor

M. T. Walling, Jr.

R. G. Wheeler

$76-80$

O. J. Wick

81

Technical Information Files

Technical Publications 
EXTERNAL DISTRIBUTION (SPECIAL) (contd.)

Number of Copies

3

Dow Chemical Company, Rocky Flats

Attn: R. Forrest (2)

L. A. Matheson

9

General Electric Company, Richland

Attn: L. I. Brecke

W. J. Gartin

H. H. Hopkins

G. C. Oberg

A. E. Smith

I. N. Taylor

R. E. Tomlinson

R. E. Van der Cook

C. M. Walker

University of California, Livermore (BML)

Attn: W. J. Ramsey (2)

J. L. Robins

\section{RLOO}

Attn: M. R. Keegan

R. K. Sharp

J. H. Sako

Technical Information Library 